Check for updates

Cite this: RSC Adv., 2018, 8, 20928

Received 26th March 2018

Accepted 20th May 2018

DOI: $10.1039 / c 8 r a 02633 e$

rsc.li/rsc-advances

\section{A 3D bioinspired highly porous polymeric scaffolding system for in vitro simulation of pancreatic ductal adenocarcinoma}

\author{
Stella Totti, (D) ${ }^{a}$ Mark C. Allenby, ${ }^{b}$ Susana Brito Dos Santos, ${ }^{\mathrm{b}}$ Athanasios Mantalaris ${ }^{\mathrm{b}}$ \\ and Eirini G. Velliou (D)*a
}

Pancreatic ductal adenocarcinoma is an aggressive disease with an extremely low survival rate. This is due to the (i) poor prognosis and (ii) high resistance of the disease to current treatment options. The latter is partly due to the very complex and dense tissue/tumour microenvironment of pancreatic cancer, which contributes to the disease's progression and the inhibition of apoptotic pathways. Over the last years, advances in tissue engineering and the development of three-dimensional (3D) culture systems have shed more light into cancer research by enabling a more realistic recapitulation of the niches and structure of the tumour microenvironment. Herein, for the first time, 3D porous polyurethane scaffolds were fabricated and coated with fibronectin to mimic features of the structure and extracellular matrix present in the pancreatic cancer tumour microenvironment. The developed 3D scaffold could support the proliferation of the pancreatic tumour cells, which was enhanced with the presence of fibronectin, for a month, which is a significantly prolonged in vitro culturing duration. Furthermore, in situ imaging of cellular and biomarker distribution showed the formation of dense cellular masses, the production of collagen-I by the cells and the formation of environmental stress gradients (e.g. HIF-1 $\alpha$ ) with similar heterogeneity trends to the ones reported in in vivo studies. The results obtained in this study suggest that this bioinspired porous polyurethane based scaffold has great potential for in vitro high throughput studies of pancreatic cancer including drug and treatment screening.

\section{Introduction}

Pancreatic ductal adenocarcinoma (PDAC) is an aggressive malignancy, being the fourth leading cause of cancer deaths in the USA, the fifth in the United Kingdom and the seventh worldwide. ${ }^{1,2}$ The 5 year survival rate, which has barely improved over the last 4 decades, is $8 \% .^{2}$ The high disease mortality is due to (i) the lack of symptoms which leads to late stage diagnosis, ${ }^{3}$ (ii) the high metastatic likelihood ${ }^{4}$ and (iii) the high resistance to currently available treatment options. ${ }^{5}$ The latter can be partly attributed to the disease's complex tumour microenvironment (TME) ${ }^{6-9}$ which consists of intense extracellular matrix (ECM) fibrosis (desmoplasia) ${ }^{6,10-12}$ that can contribute to the disease's progression and inhibition of apoptotic pathways, both increasing treatment resistance. ${ }^{13-15}$ Classically used systems for studying pancreatic cancer are either $2 \mathrm{D}$ in vitro systems or animals. While $2 \mathrm{D}$ in vitro systems are easy to use and responsive to radiation and drugs ${ }^{\mathbf{8 , 1 6 , 1 7}}$ they cannot accurately simulate

${ }^{a}$ Bioprocess and Biochemical Engineering Group (BioProChem), Department of Chemical and Process Engineering, University of Surrey, Guildford, GU2 7XH, UK. E-mail: e.velliou@surrey.ac.uk; Fax: 0044-(0)-1483686577

${ }^{b}$ Biological Systems Engineering Laboratory (BSEL), Department of Chemical Engineering, Imperial College London, London, SW7 2AZ, UK important 3D in vivo TME aspects such as structure, porosity, presence of ECM proteins, realistic cell-cell and cell-ECM interactions, environmental gradients (nutrient, oxygen) and vascularisation. ${ }^{\mathbf{8}, 18-21}$ Several animal model systems have been developed for pancreatic cancer, ${ }^{22,23}$ the best of which involve genetic modification, that have provided considerable insights into the pathogenesis of the disease. However, they are time consuming, expensive to generate and maintain and they are not always reproducible. ${ }^{23-29}$ Advances in tissue engineering enable the development of 3D constructs that are generally less expensive than animals, more reproducible and easy to develop while they provide a more realistic structure, cell-cell, cell-ECM spatial interactions and a more realistic distribution of environmental parameters within the system, such as nutrients and oxygen, chemotherapeutic diffusion, and irradiation deposition as compared to 2D systems. ${ }^{8,30-36}$

Current 3D in vitro systems of pancreatic tumours include (i) spheroid/organoid systems, ${ }^{37-45}$ (ii) hydrogel scaffolds ${ }^{42,46-48}$ and (iii) polymeric scaffolds. ${ }^{49-51}$ For example, Ware et al. have developed pancreatic cancer spheroids with a distinct cohesiveness of the cellular masses. ${ }^{43}$ Additionally, Longati et al. showed that pancreatic cancer cell lines in spheroids exhibited decreased cellular proliferation, increased ECM production and resistance to chemotherapeutic reagents as compared to a $2 \mathrm{D}$ monolayer 
culture. ${ }^{37}$ The increased chemo-resistance of pancreatic tumour spheroids in comparison with conventional 2D systems was also reported by Wen et al. ${ }^{44}$ Some features of the complex pancreatic cancer TME have been shown within spheroids. For example, Ware et al. developed a stroma rich spheroid matrix that exhibited regions of increased collagen expression compared to the non-stromal rich control system. ${ }^{41}$ Furthermore, Boj et al. constructed 3D matrigel based organoids of primary PDAC cells in order to model in vitro some essential histological and genetic characteristics of this malignancy. ${ }^{39,40}$ Raza et al. developed polymeric hydrogels of various stiffness levels. It was observed that the stiffness of the polymeric matrix affected the cellular proliferation. ${ }^{48}$ Similar results were reported by Ki et al. who observed increased pancreatic cancer cell growth after 7 days of culture for softer thiol-ene based hydrogels. ${ }^{47}$ Additionally, Chiellini et al. created two types of microstructured hydrogels, fabricated either with chitosan (CS) or with a polyelectrolyte complex formed between CS and poly $(\gamma$-glutamic acid) $(\gamma$-PGA). BxPC-3 pancreatic tumour cells proliferated in those hydrogels for 28 days, they formed aggregates and they retained cancer typical features, i.e. loss of polarity and duct-like structures. Additionally, fascin (a marker of tumour invasiveness), was expressed in the hydrogels, but not in 2D monolayer systems. ${ }^{\mathbf{4 6}}$

There are a few limited studies investigating the potential of 3D polymeric scaffolds as a pancreatic cancer model. More specifically, Wang et al. showed that a fibrous polyglyconate/ gelatine scaffold ( $4 \mathrm{~mm}$ inner diameter) supported the proliferation of pancreatic cancer stem cells (CSCs) in vitro for 7 days as well tumour formation and metastasis, when it was transplanted in mice. ${ }^{50}$ Furthermore, He et al. created a fibrous polymeric scaffolding system based on poly (glycolide-co-trimethylene carbonate) and gelatine for pancreatic tumour growth. This polymeric scaffold model demonstrated better neoplastic formation and accelerated tumour evolution as compared with the $2 \mathrm{D}$ system. ${ }^{51}$ Ricci et al. developed three different biocompatible scaffolds based on two polymers [poly (ethylene oxide terephthalate)/poly(butylene terephthalate) and poly(vinyl alcohol)/gelatine] and two polymeric formulations (fibre mesh and sponge like). The type of polymer and the formulation technique altered the internal architecture of the scaffold, which affected the cell growth and morphology as well as the tumour-specific metalloproteinases (MMPs) synthesis of PDAC. ${ }^{49}$

Among existing tissue engineering systems, polymeric scaffolds provide a more robust control of the internal structure (pore shape, size and interconnectivity) enabling the TME structural recapitulation. ${ }^{\mathbf{8 , 2 1 , 3 0 , 4 9 , 5 2 - 5 6}}$ Additionally, surface modification of the scaffolds with proteins enables the ECM mimicry which is crucial in tissue and/or tumour development. ${ }^{21,55,57,58}$ Furthermore, the high mechanical strength of polymeric scaffolds allows the introduction of perfusion in the system for vascularization mimicry with tuneable flow rates. ${ }^{52,54}$ Overall, the above features enable the recapitulation of realistic cell-cell interactions and distributions, cell-matrix interactions as well as the formation of realistic oxygen and nutrient gradients. These gradients can be more controlled, tuned and less acute/extreme in highly porous polymeric scaffolds as compared to cell aggregate based 3D systems. ${ }^{\mathbf{8 , 3 5}}$ Therefore, polymeric scaffolds are a promising platform for pancreatic cancer in vitro studies.

Natural and synthetic are the two main categories of polymers that are used for scaffold fabrication in tissue engineering. However, natural polymers are not preferred for loadbearing tissue applications due to their limited mechanical and physical stability and therefore synthetic polymers are currently the dominant scaffolding matrices in tissue engineering and regenerative medicine. ${ }^{59-61}$ Among the synthetic polymers, polyurethanes (PUs) are considered very promising candidates in tissue engineering due to their unique segmented structure, their wide range of mechanical and physical properties, their assortment from stable to degradable materials and their biocompatibility. ${ }^{61,62}$ PUs have been used as scaffolding materials for soft, ${ }^{63}$ cartilage, ${ }^{64}$ bone tissue engineering, ${ }^{65}$ and to recapitulate normal and abnormal haematopoiesis. ${ }^{21,52,55}$ Nevertheless, they have not been used to date for pancreatic cancer tissue engineering.

In this study, we report for the first time the use of a highly porous 3D polyurethane (PU) scaffolding system as a platform for pancreatic cancer modelling. Surface modification of the scaffold took place with fibronectin (FN) for enhancement of cellular adhesion. The cellular evolution including proliferation, morphology and cell mass formation in the scaffold was monitored for 29 days. Furthermore, sectioning of the scaffolds, fluorescent staining and imaging with confocal laser scanning microscopy (CLSM) enabled the spatial 3D determination of environmental (stress) gradients, i.e., oxidative, starvation, and ECM production within the 3D scaffolding system.

\section{Materials and methods}

\subsection{Fabrication and sterilisation of the 3D scaffolds}

The PU scaffolds were fabricated by the Thermally Induced Phase Separation (TIPS) method, which is described in Fig. 1. ${ }^{21,55,66,67}$ PU beads (Noveon, Belgium) were dissolved in dioxan $(5 \% \mathrm{w} / \mathrm{v})$ (99.8\% anhydrous pure, Sigma-Aldrich, UK) and the solution was quenched at $-80{ }^{\circ} \mathrm{C}$ for $2 \mathrm{~h}$. Thereafter, the solvent was removed by freeze drying in a poly-ethylene glycol (PEG) bath at $-15{ }^{\circ} \mathrm{C}$ under 0.01 mbar vacuum pressure. The scaffolds were then cut in $5 \times 5 \times 5 \mathrm{~mm}^{3}$ cubes. The average pore size was $100-150 \mu \mathrm{m}$, the porosity $85-90 \%$, as determined by Mercury Intrusion Porosimetry (MIP) (PoreMaster33, Quantachrome) and the specific pore volume obtained using helium displacement pycnometry (AccuPyc, $1330 \mathrm{V3} .00$ ) was $2.3 \pm 0.48$ $\mathrm{cm}^{3} \mathrm{~g}^{-1}$. The compression modulus was $28 \pm 3 \mathrm{kPa}$, as reported previously by Safinia et al. ${ }^{67}$ Sterilisation of the scaffolds took place by washing them with $70 \% \mathrm{v} / \mathrm{v}$ ethanol solution for $3 \mathrm{~h}$ followed by exposure to a UV/ozone generator for $10 \mathrm{~min}$ (BioForce Nanosciences, USA).

\subsection{Surface modification of the 3D scaffolds}

The PU scaffolds were coated with fibronectin (FN) from bovine plasma (Sigma-Aldrich, UK), to mimic a crucial ECM protein 


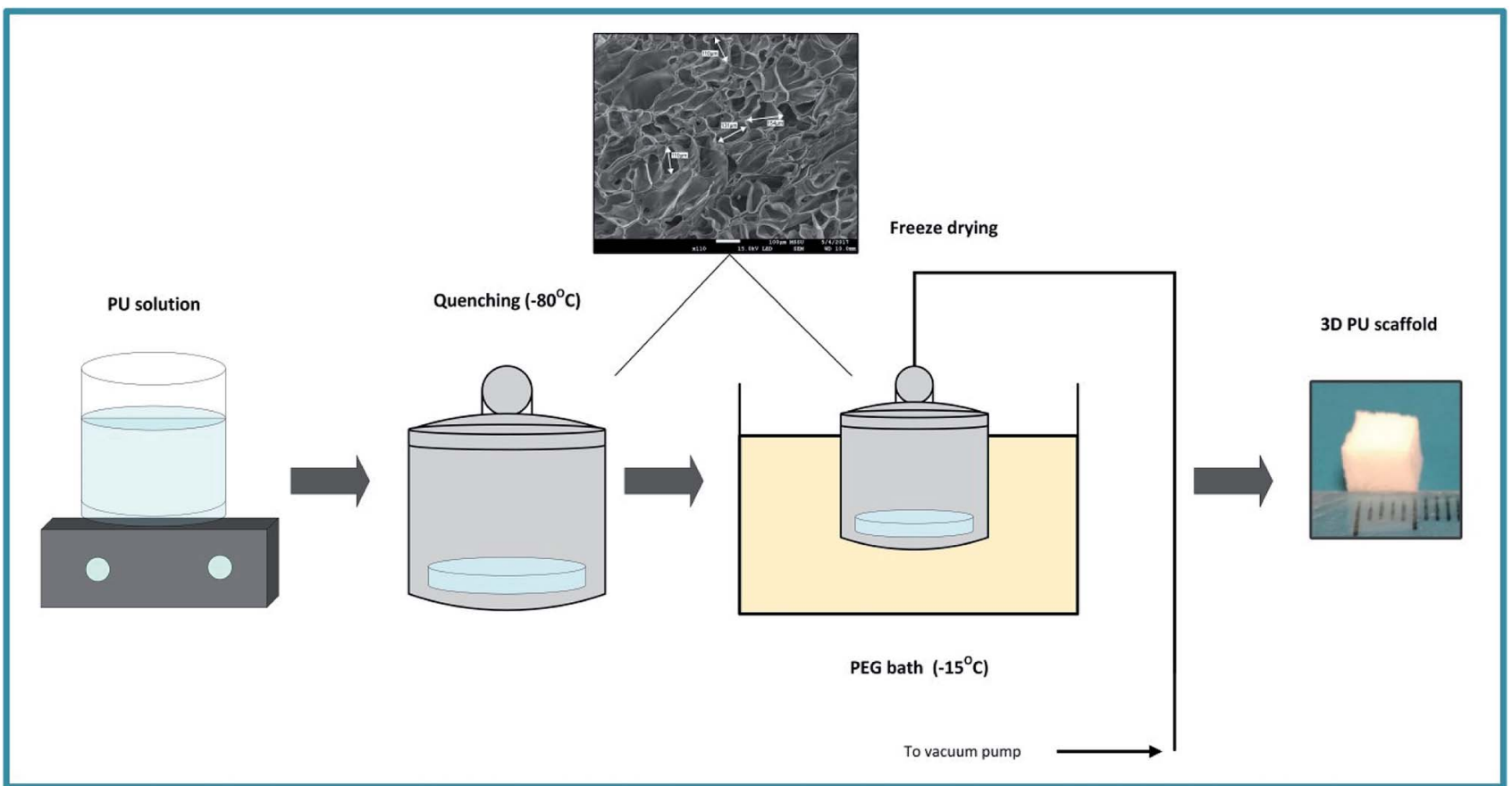

Fig. 1 Schematic representation of the PU scaffold fabrication process with the Thermally Induced Phase Separation (TIPS).

dominant in pancreatic cancer as well as to enhance the cell adhesion on the PU matrix. The protein coating took place via adsorption of the FN on the PU. ${ }^{68,69}$ More specifically, as previously described, ${ }^{21,55}$ the scaffolds were dipped in PhosphateBuffered Saline (PBS, Sigma-Aldrich, UK) for $10 \mathrm{~min}$ and centrifuged (in PBS) for $10 \mathrm{~min}$ at $2500 \mathrm{rpm}$. Then, they were transferred to the FN solution and centrifuged for $20 \mathrm{~min}$ at $2000 \mathrm{rpm}$. Centrifuging ensures better penetration and uniform distribution of the protein solution in the PU matrix. Then, one more centrifugation step in PBS for $10 \mathrm{~min}$ at $1500 \mathrm{rpm}$ is carried out to unblock the surface pores of the scaffolds. The FN coating concentration was $25 \mu \mathrm{g} \mathrm{mL}^{-1}$. $^{21,55,70,71}$

\subsection{D cell culture}

The human pancreatic adenocarcinoma cell lines AsPC-1 (ATCC $®$ UK, CRL-1682) and PANC-1 (Sigma-Aldrich UK, ECAAC 87092802) were expanded in tissue culture plastic flasks (Fisher Scientific, UK) in Dulbecco's modified Eagle's medium (DMEM) with high glucose (Lonza, UK), while the BxPC-3 (ATCC $®$ UK, CRL-1687) cell line was cultured in Roswell Park Memorial Institute (RPMI) 1640 medium (Lonza, UK) with high glucose, according to the supplier's culture protocol, in a humidified incubator at $37{ }^{\circ} \mathrm{C}$ and $5 \% \mathrm{CO}_{2}$ until an adequate number of cells for each experiment was achieved. Both culture media were supplemented with $10 \% \mathrm{v} / \mathrm{v}$ heat inactivated foetal bovine serum (Fisher Scientific, UK), $100 \mathrm{U} \mathrm{mL}^{-1}$ penicillin/ streptomycin (Sigma-Aldrich, UK) and $2 \mathrm{mM}$ L-glutamine (Sigma-Aldrich, UK) stock solutions. Mycoplasma negative cultures were ensured by regular mycoplasma screening tests (Lonza, UK).
For all conditions under study, $100 \mu \mathrm{L}$ of cell suspension $(5 \times$ $10^{5}$ cells per $100 \mu \mathrm{L}$ ) was seeded in sterile scaffolds, which were placed in 24 well-plates and allowed to settle for $15 \mathrm{~min}$ in an incubator at $37^{\circ} \mathrm{C}$ in a $5 \% \mathrm{CO}_{2}$ atmosphere. Then, $1.5 \mathrm{~mL}$ of the appropriate cell culture medium was added in each well. Scaffolds were placed in an incubator at $37^{\circ} \mathrm{C}, 5 \% \mathrm{CO}_{2}$ and $20 \% \mathrm{O}_{2}$. Cell growth was monitored for 29 days (5 weeks). Cell culture medium was replenished every two to three days. In order to avoid cell confluency at the bottom of the wells resulting from scaffold egress, scaffolds were placed in a new well-plate on a weekly basis.

\subsection{MTS cell viability assay}

Quantitative assessment of cell viability/proliferation in the scaffolds took place by measuring the increase of metabolically active cells using the tetrazolium compound [3-(4,5-dimethylthiazol-2-yl)-5-(3-carboxymethoxyphenyl)-2-(4-sulfophenyl)$2 H$-tetrazolium] MTS reagent (Promega, CellTiter96® Aqueous Solution Cell Proliferation Assay, WI USA). The reagent was supplemented to fresh culture medium at a ratio of $1: 5$ according to the manufacturer's protocol and added to the $3 \mathrm{D}$ scaffold cultures prior to a $3 \mathrm{~h}$ incubation at $37^{\circ} \mathrm{C}$, according to the manufacturer's protocol. Afterwards, the absorbance was measured at $490 \mathrm{~nm}$ on a plate reader (Synergy HT, BioTek, VT, USA).

\subsection{Scanning electron microscopy (SEM)}

The 3D scaffolds were sectioned and the cell distribution and adhesion on/in the pores of the matrix was observed with scanning electron microscopy (SEM). More specifically, scaffolds were collected at the beginning (day 1) and at the culture 
Table 1 Primary and isotype antibody concentrations for the immunofluorescence (IF) assay ${ }^{a}$

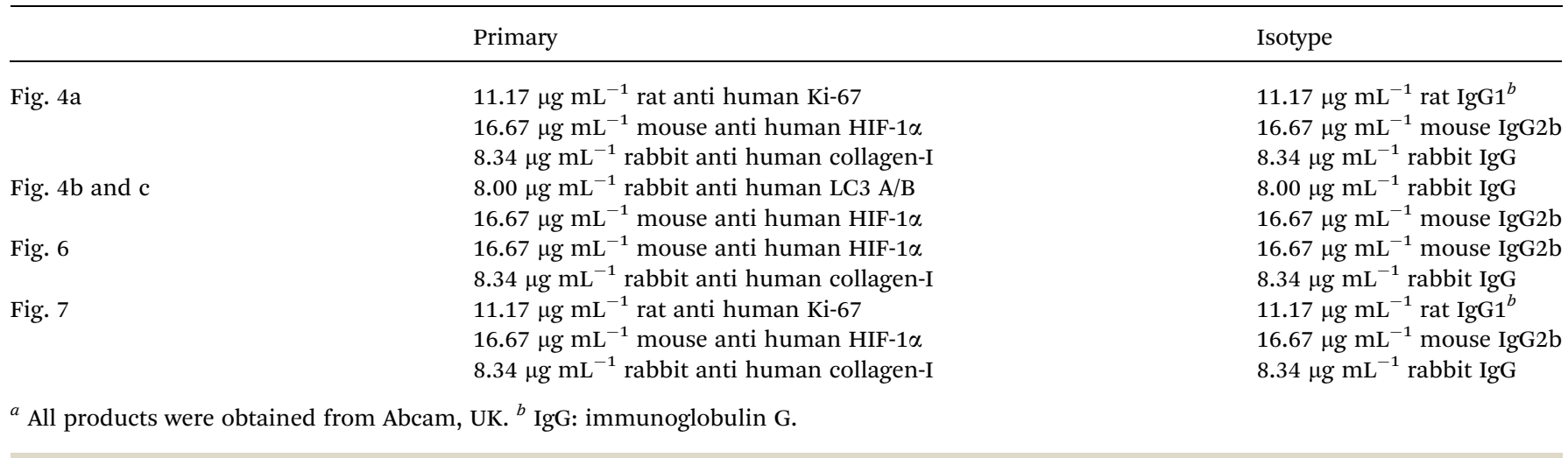

endpoint (day 29), snap frozen in liquid nitrogen for $15 \mathrm{~min}$ and then preserved in $-80{ }^{\circ} \mathrm{C}$ until fixation. At fixation, samples where sectioned approximately in the middle with a razor and then directly immersed in $4 \% \mathrm{v} / \mathrm{v}$ cold formaldehyde solution (Sigma-Aldrich, UK) for $2 \mathrm{~h}$ at room temperature. Thereafter, post fixation took place including 2 washing steps with PBS for 15 min each, followed by 4 washing steps with deionized water for $15 \mathrm{~min}$ each to ensure removal of the residual crystals. Afterwards, the scaffold sections were air dried overnight in an aseptic environment. The specimens were sputter coated with gold in an argon atmosphere $24 \mathrm{~h}$ prior the SEM imaging. The scanning electron microscopy was performed on a JOEL JMS610LA (JEOL USA, MA, USA) microscope at different magnifications.

\subsection{Immunofluorescence assays}

In situ immunofluorescence (IF) staining of the scaffolds took place for the spatial determination of the (i) cell organisation and/or cell masses formations (4',6-diamidino-2-phenylindole, DAPI), (ii) cell proliferation (Ki-67), (iii) ECM production (collagen-I), (iv) potential environmental stress gradients, i.e., oxygen/oxidative stress (HIF-a) and nutrient/starvation stress (LC3). More specifically, scaffolds were collected at the middle (day 15) and the end of the culturing period (day 29), snap frozen in liquid nitrogen for $15 \mathrm{~min}$ and then preserved at $-80{ }^{\circ} \mathrm{C}$ until sectioning as previously described..$^{52}$ Prior to the IF assay preparation, multiple scaffold sections of $\sim 1 \mathrm{~mm}$ were generated. Briefly, the preparation included overnight fixation in $4 \% \mathrm{w} / \mathrm{v}$ paraformaldehyde, then $2 \mathrm{~h}$ permeabilisation in $0.1 \%$ Triton X-100 (Sigma Aldrich, UK) at room temperature followed by $4 \mathrm{~h}$ blocking in $10 \%$ of donkey serum (Abcam, UK), overnight primary antibody staining, $6 \mathrm{~h}$ secondary antibody staining and overnight counterstaining all at $4{ }^{\circ} \mathrm{C}$. Cells and scaffold structure were evaluated with a Leica SP5 inverted confocal microscope and processed with Leica LAS AF software (Leica, Milton Keynes, UK). Each step employed solvents of either $1 \% \mathrm{w} / \mathrm{v}$ bovine serum albumin (Sigma-Aldrich, UK), 0.5\% v/v Tween20 (Promega, UK) and $0.01 \% \mathrm{w} / \mathrm{v} \mathrm{NaN}_{3}$ in PBS, or only $0.01 \%$ $\mathrm{w} / \mathrm{v} \mathrm{NaN}_{3}$ in PBS after secondary antibody staining. Each step was separated by at least two washes with above solvent buffer. Primary antibodies and isotype controls are summarised in
Table 1. Secondary antibodies consisted of: donkey anti rat Alexa Fluor 488 (AF 488), donkey anti mouse Alexa Fluor 555 (AF 555) and donkey anti rabbit 647 (AF 647; all Fisher Scientific, UK) at $1: 500$ dilution. Counterstain consisted of: $5 \mu \mathrm{g} \mathrm{mL}$ DAPI (Fisher Scientific, UK).

\subsection{Cell viability confocal imaging}

As described in section 2.6, scaffolds were collected at day 29, snap frozen in liquid nitrogen for $15 \mathrm{~min}$ and then preserved at $-80{ }^{\circ} \mathrm{C}$. After sectioning, each scaffold section was incubated with Calcein-AM ( $2 \mu \mathrm{M}$; Life Technologies, Paisley, UK) and ethidium homodimer-1 ( $4 \mu \mathrm{M}$; Life Technologies) in culture medium for $1 \mathrm{~h}$ at $37^{\circ} \mathrm{C}$. The presence of live (green) and dead (red) cells was immediately evaluated with Leica SP5 inverted confocal microscope and processed with Leica LAS AF software (Leica, Milton Keynes, UK).

\subsection{Confocal laser scanning microscopy (CLSM) imaging}

Immunofluorescent samples were imaged on a Leica SP5 inverted confocal microscope and processed with Leica LAS AF software (Leica, Milton Keynes, UK) using 405, 453, 488, 543, and $633 \mathrm{~nm}$ lasers and filters for DAPI, reflectance, AF488, AF555, and AF647 stains for 2 sequential scans. Confocal images were captured using a $10 \times$ dry objective, with a $512 \times$ 512 pixel resolution and $5 \mu \mathrm{m} \mathrm{Z}$-stack distance, as previously described. ${ }^{52}$ Those image acquisition settings were identical for the positive and the corresponding isotype control. Multiple replicates from multiple scaffold areas where imaged and representative images are presented.

\subsection{Statistical analysis}

Statistical analyses were performed from $N=3$ independent cultures where $n=2-3$ replicate scaffold measurements per culture were averaged. Error bars represent standard deviation. Analysis of variance (One-way or Two-way ANOVA) and unpaired, 2-tailed Student's $t$-test was performed using GraphPad Prism ${ }^{\circledR}$ software with a $p$-value threshold 0.05 to evaluate whether there was a statistical difference between the experimental conditions under study. 


\section{Results}

3.1. Long term cultivation of pancreatic cell lines in the PU scaffolding system

AsPC-1, PANC-1 and BxPC-3 pancreatic cancer cell lines were seeded $\left(5 \times 10^{5}\right.$ cells $)$ in uncoated PU scaffolds and cell viability/ proliferation was monitored for 29 days. As shown in Fig. 2, high viability was maintained for all the cell lines in the $3 \mathrm{D}$ scaffolds. Furthermore, a significant increase in the proliferation took place, for the AsPC-1 and PANC-1 cell lines (Fig. 2a and b). BxPC-3, did not present any significant increase in absorbance indicating a low level of growth rate (Fig. 2c), which is consistent with previously reported $2 \mathrm{D}$ studies. ${ }^{72}$

\subsection{In situ cellular characterisation in the PU scaffolding system}

Cell self-organisation in the 3D cultures. Scanning electron microscopy (SEM) micrographs verified the ability of the uncoated PU scaffolds to support cellular self-organisation within scaffold pores. As can be seen in Fig. 3 pancreatic cancer cells were distributed as single cells at the beginning of the culturing period (Fig. $3 \mathrm{a}$ and $\mathrm{b}$ ), and formed dense masses at the culture endpoint (Fig. 3c-f).

Long term proliferation and maintenance of dense cellular masses in the 3D cultures. As described in section 2.6, in situ immunofluorescent staining of scaffold sections took place. Only scaffolds with PANC-1 cells were used for this purpose, as these cells are considered more aggressive than AsPC-1 and BxPC-3. ${ }^{73}$ A high number of cells (blue) was present and homogeneously distributed throughout the scaffold section from which a significant amount was proliferative (Ki-67 positive) on day 29 of culture (Fig. 4a). Furthermore, the cells that were closer to the edges of the scaffold have not experienced oxidative stress (HIF- $1 \alpha$ negative) and a region of hypoxic cells (see red arrows in Fig. 4a and c) was present at the centre, which confirms that the highly porous scaffolding system provided sufficient oxygen for long term cell growth. Collagen-I secretion was not detected in the uncoated PU scaffolds. In order to further investigate the possible presence of nutrient gradients in the centre of the scaffolding system, cells were stained with LC3-A/B antibody (yellow), the autophagic marker that is mainly overexpressed as a response to nutrient deprivation (metabolic stress). ${ }^{8,74}$ As indicated in Fig. $4 \mathrm{~b}$ and c, the cells were LC3 negative both at the beginning and at the end of the culturing period.

\subsection{Engineering the PU scaffolding system to recapitulate ECM features}

The ECM mimicry enhanced pancreatic cancer cell growth in the scaffolds. The PU scaffolds were coated with fibronectin, one of the key proteins in the pancreatic cancer ECM network, ${ }^{75}$ to enhance the cell adhesion on the polymeric matrix. Fig. 5a shows the growth kinetics of PANC-1 cells seeded and cultured in uncoated (PUN) and FN coated (PFN) PU scaffolds. The FN coated scaffolds significantly promoted the cellular proliferation $(P<0.01)$ as compared to the uncoated scaffolds at day 29 of
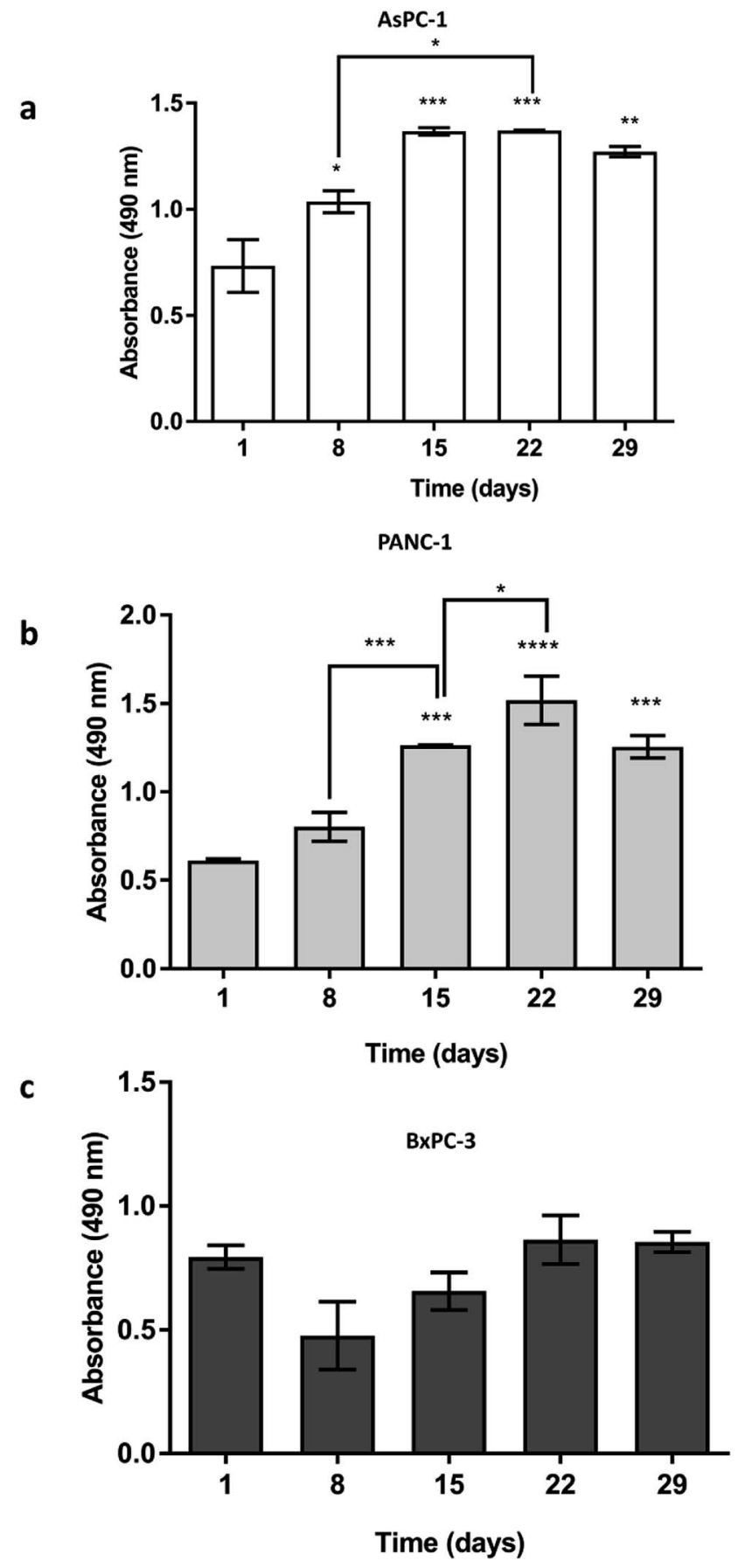

Fig. 2 Growth of (a) AsPC-1, (b) PANC-1 and (c) BxPC-3 pancreatic cancer cell lines in uncoated PU scaffolds for 29 days. Data are presented as mean \pm S.D $(N=3, n=3)$. Statistical differences for the cell growth are marked by asterisks $(* p<0.05$; $* * p<0.01$; $* * p<0.001$; $* * * *<0.0001$ ). $N=$ number of independent experiments; $n=$ number replicates.

culture (Fig. 5a). This is further confirmed with the in situ live/ dead staining results on the $29^{\text {th }}$ day of culture that revealed a greater number of live cells masses within the FN coated scaffolds as compared to the uncoated ones (Fig. 5b and c). Nevertheless, all the PU scaffolds (uncoated/FN coated) presented high viability validating the biocompatibility of this scaffolding system for pancreatic cancer cells (Fig. 5b and c). 

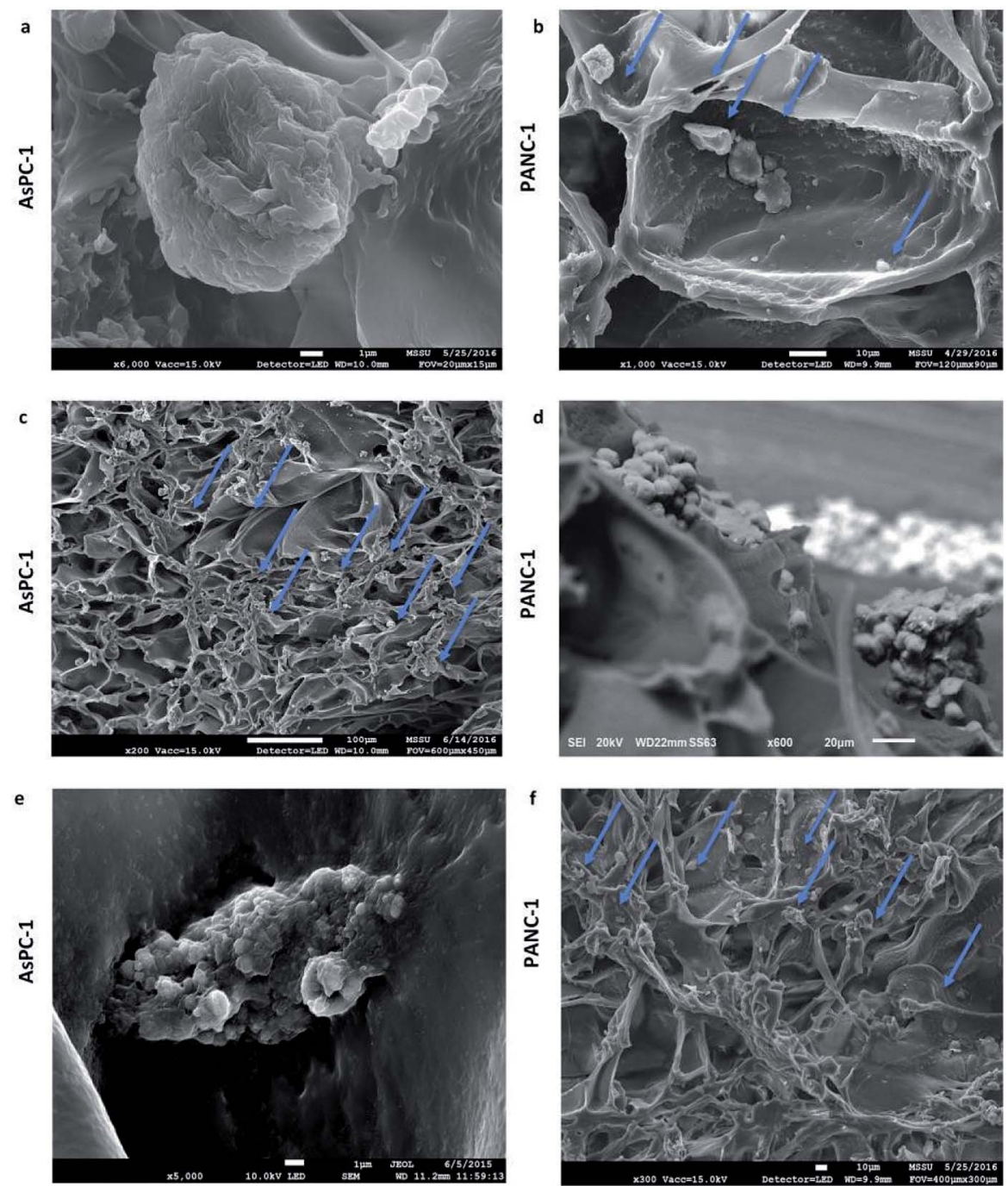

Fig. 3 Scanning electron microscopy images of AsPC-1 and PANC-1 cells in sections of the uncoated (UN) PU scaffolds at day 1 (a and b) and day 29 (c-f) of culture.

In situ fluorescence imaging of FN coated 3D scaffolds for determination of the spatial distribution of cells biomarkers with CLSM. As previously described, the coated scaffolds were sectioned and appropriately stained to determine the cell spatial growth, organisation, ECM production and environmental stress response. CLSM imaging revealed that cellular growth and spatial organisation is influenced by the coating of the scaffolds with FN (Fig. 6). Cells within the FN coated scaffolds (PFN) formed dense masses at day 15 (Fig. 6a) which expanded through day 29 (Fig. 6c). In contrast, cells within uncoated scaffolds (UN) formed smaller masses (Fig. 6b and d). Collagen-I is overexpressed in pancreatic cancer tumours in vivo and therefore it was selected as an ECM marker. ${ }^{76}$ The scaffold IF staining demonstrated that collagen-I detection varied between FN coated versus uncoated ones. A greater number of cells were imaged secreting collagen-I in FN coated scaffolds (indicated with yellow arrows in Fig. 6a and c). However, no collagen-I production was detected in uncoated scaffolds (Fig. 6b and d).
Finally, staining and imaging a wide scaffold area at the endpoint of the culture provides a map of the cellular distribution, the ECM production and the oxidative stress (HIF-1 $\alpha$ ) biomarker expression within the scaffold. Spatial variations in collagen-I, HIF- $1 \alpha$ and Ki-67 expression as well as cell selforganisation are presented in Fig. 7. Different densities of cell masses, most of them maintaining their proliferative properties (Ki-67 positive), were formed within the PU matrix. The cell masses were surrounded by collagen-I molecules and expressed locally oxidative stress gradients (HIF-1 $\alpha$ ) (Fig. 7).

\section{Discussion}

Overall, in this work, a 3D highly porous PU scaffold coated with fibronectin (FN) was developed and assessed as an in vitro platform for pancreatic cancer studies. The developed scaffolding system was able to support the long term cellular growth and proliferation (Fig. 2, 4a and 5-7), cell self-organisation (Fig. 3 and 5-7) and ECM protein, i.e., collagen I, production 
PANC-1
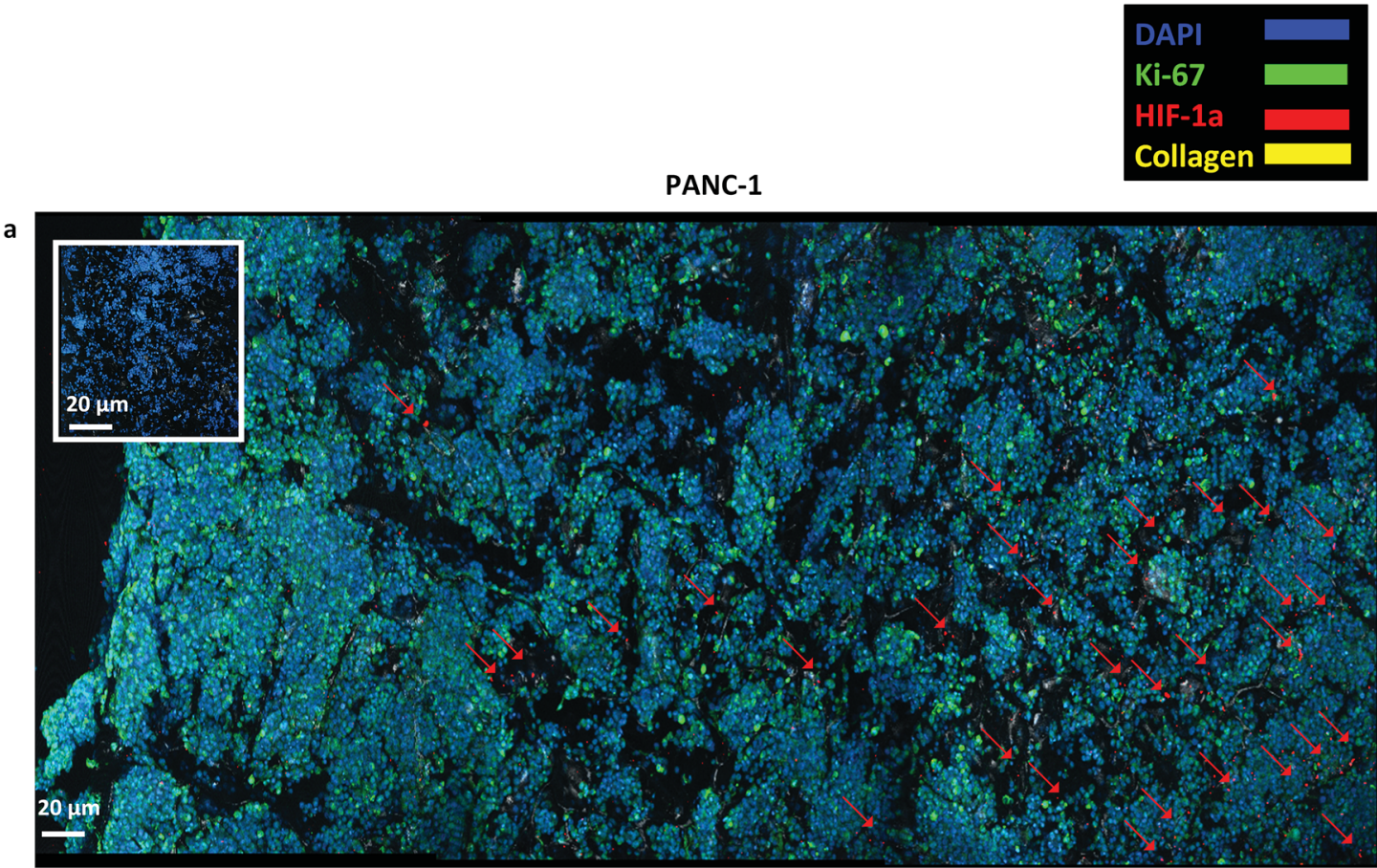

PANC-1

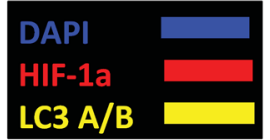

b

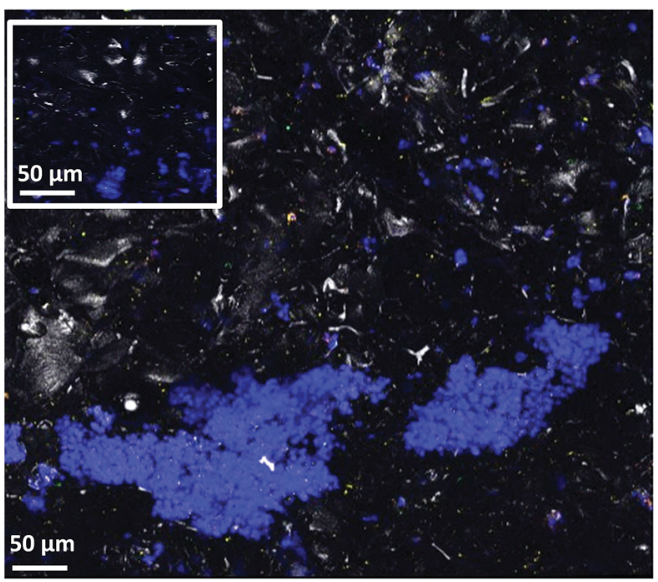

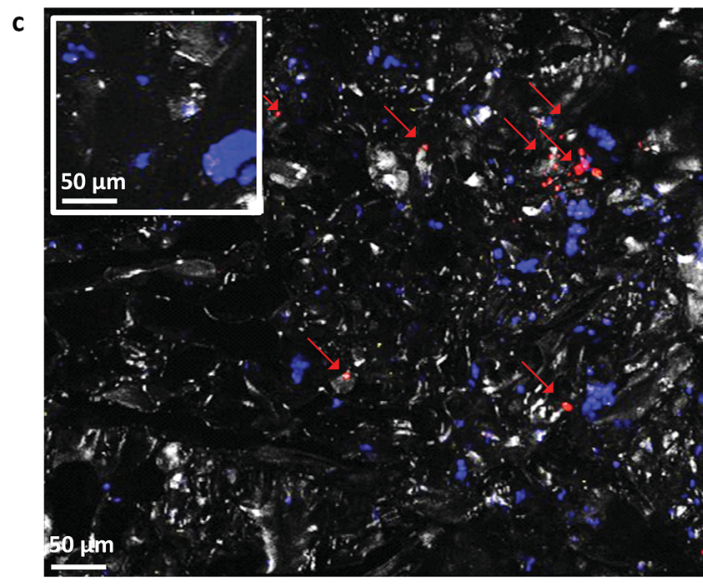

Fig. 4 (a) Representative immunofluorescence CLSM images of Ki-67, HIF-1 $\alpha$ and collagen-I distribution in sections of uncoated PANC-1 PU scaffolds at day 29 of culture. (b and c) Representative immunofluorescence CLSM of HIF-1 $\alpha$ and LC3-A/B distribution in uncoated PANC-1 PU scaffolds at day 1 (b) and day 29 (c) of culture. For each image the corresponding isotype control was generated.

of pancreatic cancer cells (Fig. 5 and 6). Furthermore, in situ mapping of various environmental stress biomarkers, i.e., oxygen and nutrient stress, revealed the formation of some oxygen/oxidative stress gradients, i.e., formation of some hypoxic areas, but no nutrient/starvation stress gradients within the scaffold (Fig. 4, 6 and 7). This is crucial, as the accurate topological identification of stress biomarkers' signals can lead to a better understanding of the 3D tumour response and/or resistance to treatment, e.g., areas of higher or lower resistance. $^{77,78}$ Furthermore, the fact that the environmental gradients are not extreme is of importance as most currently available 3D systems for pancreatic cancer induce artificially high oxygen gradients that lead to a large non-proliferative centre, which is not always present in vivo. ${ }^{32}$ To our knowledge, this is the first study that reports the long term growth and evolution of pancreatic cancer cells in a highly porous ECM coated PU scaffolding system. Some previous studies have explored pancreatic cancer cell evolution in 3D polymeric systems, however it is the first time that the PU is used as scaffolding material to generate a highly porous sponge-like 

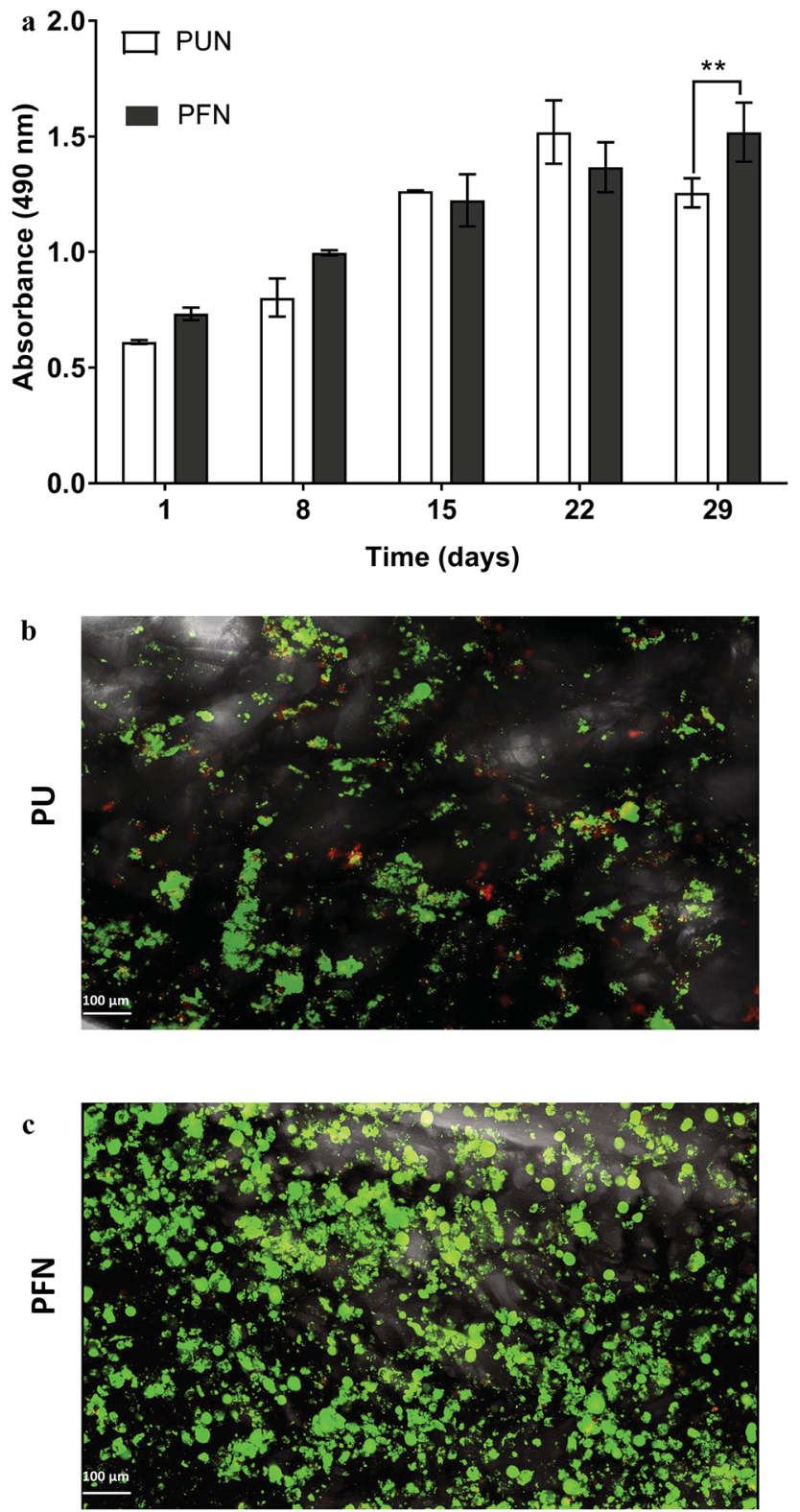

Fig. 5 (a) Growth of PANC-1 cells in uncoated (PUN) and FN coated (PFN) PU scaffolds for 29 days. Data are presented as mean \pm S.D. $(N=$ $2, n=3)$. Statistical differences are marked by asterisks $(* p<0.05 ; * * p$ $<0.01$ ). $N=$ number of independent experiments; $n=$ number replicates. ( $b$ and $c$ ) Visualization of PANC-1 cells in uncoated (PUN) and FN coated (PFN) scaffolds respectively with fluorescence Live (green, Calcein AM) and Dead (red, Ethidium homodimer-1) viability assay at day 29 of culture.

matrix which, to the authors' knowledge, resulted to the longest reported cell proliferation period of pancreatic tumour cells, along the study of Chiellini et al. Most pancreatic cancer studies in 3D systems to date report an in vitro culture period of 7-14 days. ${ }^{\mathbf{4 6 , 4 9 - 5 1}}$ Long term cultivation is important as it could enable the conduction of fractionated treatment followed by long term post-treatment observations.
Evolution of pancreatic cancer cells in the highly porous PU scaffold

The developed highly porous PU scaffolding system supported the long term cultivation and proliferation of 3 different PDAC cell lines, i.e., AsPC-1, PANC-1, BxPC-3, for 29 days (Fig. 2). It is noteworthy that the pancreatic cancer cell lines maintained their intrinsic kinetics and typical morphological characteristics within the polymeric matrices (Fig. 2 and 3). AsPC-1 and PANC-1 cells had similar growth rates in the scaffolding system, while BxPC-3 cell line had a slower growth evolution, which is in alignment with the reported duplication times of these cell lines. ${ }^{72}$ In terms of morphological characteristics within the 3D scaffold, as verified by SEM imaging, the AsPC-1 cells retained their foci-like epithelial shape (Fig. 3a), ${ }^{79,80}$ while PANC-1 cells had an elongated epithelial morphology (Fig. 3b). ${ }^{\mathbf{8 1 , 8 2}}$ This scaffolding system allowed large population of cells to grow, the majority of which were positive proliferative (Ki-67 positive) on day 29 (Fig. 4a). Similar images of cellular masses during PDAC evolution in a rat model were reported by Ignat et al. ${ }^{83}$ Likewise, another study for PDAC detection demonstrated dense cell masses in the tumour area of human pancreatic cancer xenografts. ${ }^{84}$ This suggests that this scaffolding system provides realistic in vivo recapitulation of the pancreatic tumour selforganisation facilitating high cellular densities and cell-cell interactions within the 3D structure.

The lack of nutrient gradients despite the high cell densities on day 29 of PANC-1 scaffold culture was verified since the LC3 autophagic marker (Fig. 4b and c), a marker which is mainly upregulated under starvation conditions, was not expressed. ${ }^{\mathbf{8 5}}$ Nevertheless, local hypoxic areas were present mainly where dense overpopulated masses exist, mimicking the low oxygen levels that naturally occur within the pancreatic tumour (Fig. 4a). Similar results of HIF-1 $\alpha$ expression in patient derived samples were demonstrated by Salnikov et $a l^{\mathbf{8 6}}$ Other studies have also reported the mimicry of hypoxic areas in vitro, leading however to extreme oxygen gradients which lead to high apoptotic regions which are not always reported in vivo. ${ }^{87-89}$

\section{Evolution of pancreatic cancer cells in FN coated highly porous PU scaffolds}

FN is a major ECM constituent of PDAC that mediates cell adhesion. We therefore, modified further the PU scaffolds with FN, to promote the cell adhesion, but also to provide partially the ECM mimicry to the cells. Cellular viability/proliferation in FN coated scaffolds was significantly higher as compared to the uncoated scaffolds at day 29 of culture (Fig. 5a). However, the difference in cell growth between the uncoated and FN coated scaffolds was noticeably smaller than other reported biological systems in PU scaffolds, ${ }^{55}$ showing that pancreatic cancer cell lines grow significantly well in the PU scaffolds even without ECM coating support. Similarly to our findings, Raza et al. reported the effect of FN derived peptides on PANC-1 growth in 3D PEG-based hydrogels and showed that PANC-1 cells exhibited higher proliferation at the end of the culture in the FN enriched hydrogels compared to the FN-free gels. ${ }^{48}$ Additionally, Miyamoto et al. reported that pancreatic cancer cell lines growth was 


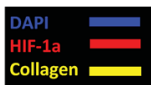

PFN-day 15

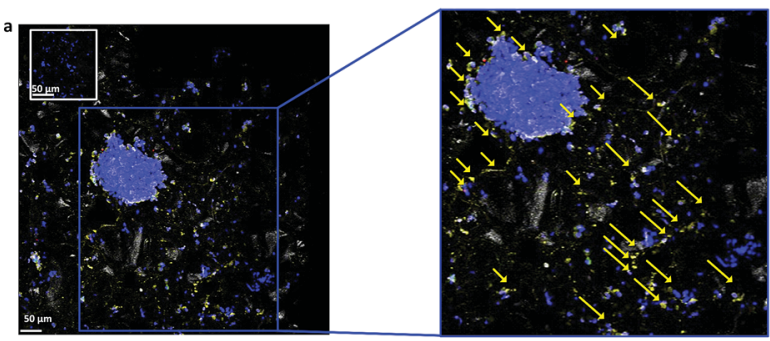

PFN-day 29

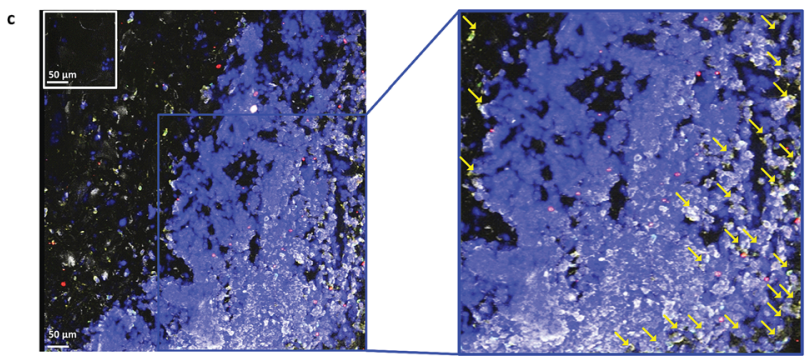

PUN-day 15

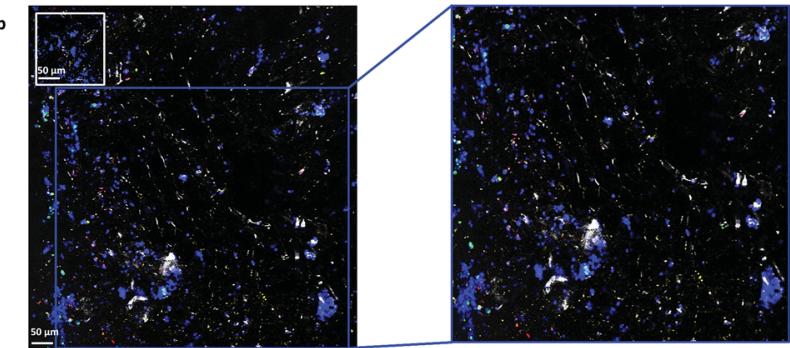

PUN-day 29

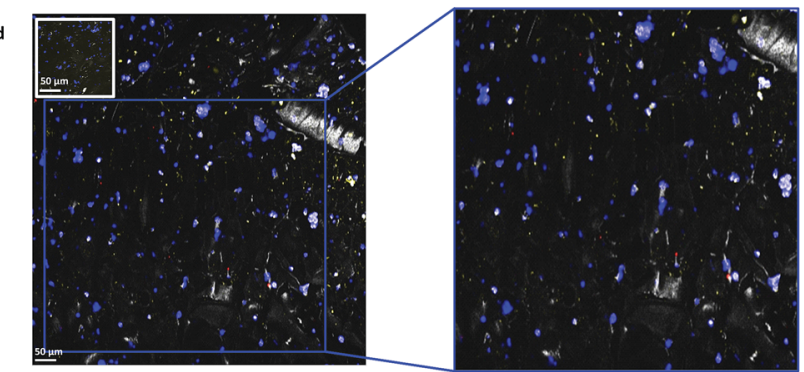

Fig. 6 Representative immunofluorescence CLSM images of HIF-1 $\alpha$ and collagen-I distribution in FN coated (a and c) and uncoated (b and d) PANC-1 scaffolds at day 15 and day 29 of culture. For each image the corresponding isotype control was generated.

enhanced on FN coated 2D monolayers compared to the controls (uncoated surfaces) at the end of the culture. ${ }^{90}$ From the above studies in both 2D and 3D systems it is evident that FN stimuli promotes cell growth in vitro. Further to the pancreatic cancer cell growth/proliferation we observed that the FN coating affected the cellular spatial self-organisation in the PU matrix. More specifically, the cells formed larger masses in the FN coated scaffolds as compared to uncoated ones where they formed smaller masses (Fig. 6). We have previously reported this formation of PANC-1 cellular masses in carbon nanotube based films. ${ }^{80} \mathrm{FN}$ is considered to interact with the cell surface integrin receptors, which may result in enhancing the cell-cell interactions and consequently leading to cell clustering. ${ }^{75,91}$ This evidence is further supported by the group of Da Rocha-Azevedo et al., who showed that the cell contraction in clustering requires the presence of $\mathrm{FN}^{92}$ Furthermore, the secretion of collagen-I was monitored, as collagen-I is an important feature of PDAC microenvironment which is highly secreted within the densely-packed pancreatic tumour stroma, as proven by patient and animal studies. ${ }^{76,93,94}$ We observed a significant collagen-I secretion in the FN coated scaffolds (Fig. 6a, c and 7) and no collagen-I secretion in uncoated scaffolds (Fig. 4a, 6b and d). Expression of high collagen levels from the pancreatic cancer cells in multilayer FN-gelatin nanofilms was also reported by Matsusaki $e t a l^{95}$

Finally, sectioning and imaging of a wide scaffold area of the FN coated scaffold (essentially 'zooming-out' the FN scaffold) enabled the biomarker mapping of a tissue-scale area, therefore, providing insightful information about on formed cell heterogeneity. It should be stated that, to best of our knowledge, this is the first reported image of this size $\left(\sim 3 \times 5 \times 1 \mathrm{~mm}^{3}\right)$, as most CSLM images of both in vivo and in vitro systems are within the range of microns..$^{46,49,83,84,86}$ As can be seen in Fig. 7, the majority of the cell population that existed in the scaffold is proliferative (Ki-67) positive on day 29 of culture, revealing the long term maintenance of the cell culture within the 3D matrix. At this point it should be mentioned that there are very few 3D systems studying the pancreatic cancer cell Ki-67 expression and none after 15 days of culture, as the centre of such 3D models usually contains arrested proliferation and accumulation of apoptotic due to oxidative stress regions. ${ }^{41,43,89}$ The pore size and interconnection of this scaffolding system allows the cells to proliferate throughout the matrix area, with local hypoxic areas (HIF-1 $\alpha$ positive) being heterogeneously distributed throughout the scaffold area (Fig. 7). This is of great importance, since hypoxia is a hallmark of all the solid tumours and due to the structural and functional abnormalities of tumour microcirculation spatial and temporal heterogeneity in the perfusion is caused. ${ }^{96,97}$ Heterogeneous HIF- $1 \alpha$ gradient accumulation in pancreatic tumours has also been reported for patient derived tissues. ${ }^{86,98}$ Additionally, collagen-I was heterogeneously expressed by the cells within the FN coated scaffolds (Fig. 7).

\section{Conclusions}

Overall, in this study we developed a 3D highly porous PU scaffolding system coated with FN which shows great potential 

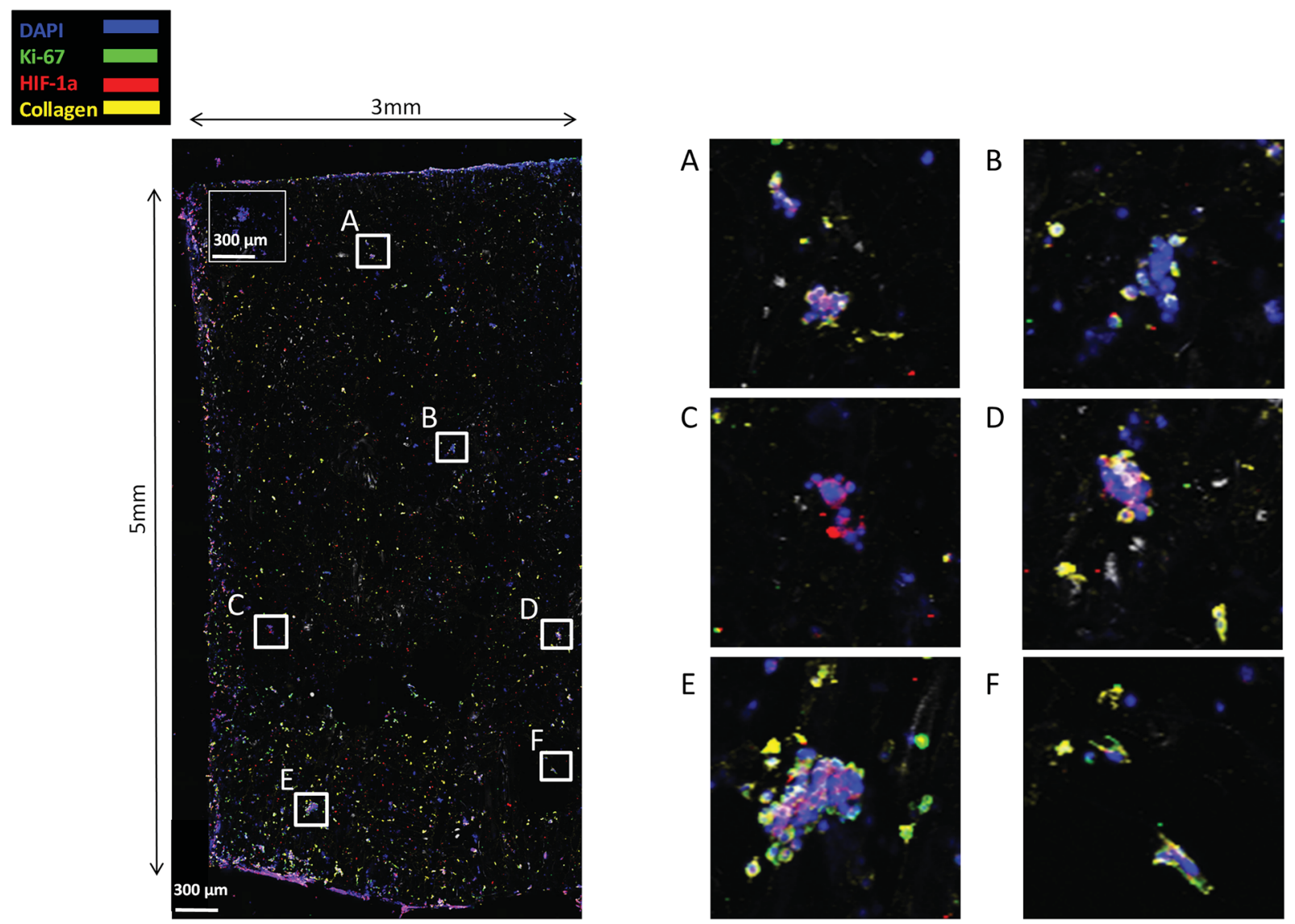

Fig. 7 CLSM image of Ki-67, HIF-1 $\alpha$ and collagen-I distribution in a wide PANC-1 FN coated scaffold area at day 29 of culture. For each image the corresponding isotype control was generated.

as a model for pancreatic cancer studies. The reported 3D model was able to (i) support long term growth and proliferation of pancreatic cancer cells for up to a month, (ii) allow formation of dense cellular masses, (iii) enhance the collagen-I production from the pancreatic cells and (iv) induce environmental gradients (hypoxic regions) which were not acute and therefore did not arrest cell proliferation. Furthermore, in situ mapping of a wide scaffold area revealed a high level of heterogeneity with respect to biomarker spatial distribution. Similar trends have been reported in vivo, indicating the great potential of the developed PU scaffolding system for pancreatic cancer studies. Future work will focus on (i) introducing perfusion in the system for vascularisation mimicry as well as (ii) co-culturing of pancreatic cancer cells with stromal cells in order to simulate even more accurately the pancreatic cancer tissue microenvironment.

\section{Conflicts of interest}

There are no conflicts to declare.

\section{Acknowledgements}

This work was supported by the Chemical and Process Engineering Department of the University of Surrey as well as an Impact Acceleration Grant (IAA-KN9149C) of the University of
Surrey, an IAA - EPSRC Grant (RN0281J) and the Royal Society. M. C. A. is grateful for the Imperial College Chemical Engineering Scholarship. M. C. A., S. B. D. S., A. M. acknowledge the support from ERC-BioBlood (no. 340719).

\section{References}

1 R. L. Siegel, K. D. Miller and A. Jemal, Ca-Cancer J. Clin., 2018, 68, 7-30.

2 American Cancer Society, Cancer Facts \& Figures 2018, Atlanta, 2018.

3 S. Cascinu, M. Falconi, V. Valentini and S. Jelic, Ann. Oncol., 2010, 21, 55-58.

4 T. Kamisawa, T. Isawa, M. Koike, K. Tsuruta and A. Okamoto, Pancreas, 1995, 11, 345-349.

5 S. Chand, K. O'Hayer, F. F. Blanco, J. M. Winter and J. R. Brody, Int. J. Biol. Sci., 2016, 12, 273-282.

6 D. Xie and K. Xie, Genes Dis., 2015, 2, 133-143.

7 M. W. Pickup, J. K. Mouw and V. M. Weaver, EMBO Rep., 2014, 15, 1243-1253.

8 S. Totti, S. I. Vernardis, L. Meira, P. A. Perez-Mancera, E. Costello, W. Greenhalf, D. Palmer, J. Neoptolemos, A. Mantalaris and E. G. Velliou, Drug Discovery Today, 2017, 22, 690-701.

9 L. G. Melstrom, M. D. Salazar and D. J. Diamond, J. Surg. Oncol., 2017, 116, 7-15. 
10 T. M. Gress, A. Menke, M. Bachem, F. Muller-Pillasch, V. Ellenrieder, H. Weidenbach, M. Wagner and G. Adler, Digestion, 1998, 59, 625-637.

11 S. Pandol, M. Edderkaoui, I. Gukovsky, A. Lugea and A. Gukovskaya, Clin. Gastroenterol. Hepatol., 2009, 7, S44S47.

12 C. J. Whatcott, C. H. Diep, P. Jiang, A. Watanabe, J. LoBello, C. Sima, G. Hostetter, H. M. Shepard, D. D. Von Hoff and H. Han, Clin. Cancer Res., 2015, 21, 3561-3568.

13 H. E. Barker, J. T. E. Paget, A. A. Khan and K. J. Harrington, Nat. Rev. Cancer, 2015, 15, 409-425.

14 C. J. Whatcott, R. G. Posner, D. D. Von Hoff and H. Han, in Pancreatic Cancer and Tumor Microenvironment, ed. P. J. Grippo and H. G. Munshi, Trivandrum, 2012.

15 N. Dumont, B. Liu, R. A. DeFilippis, H. Chang, J. T. Rabban, A. N. Karnezis, J. A. Tjoe, J. Marx, B. Parvin and T. D. Tlsty, Neoplasia, 2013, 15, 249-262.

16 K. Oonishi, X. Cui, H. Hirakawa, A. Fujimori, T. Kamijo, S. Yamada, O. Yokosuka and T. Kamada, Radiother. Oncol., 2012, 105, 258-265.

17 L. R. Jaidev, U. M. Krishnan and S. Sethuraman, Mater. Sci. Eng., C, 2015, 47, 40-47.

18 C. M. Nelson and M. J. Bissell, Annu. Rev. Cell Dev. Biol., 2006, 22, 287-309.

19 A. Birgersdotter, R. Sandberg and I. Ernberg, Semin. Cancer Biol., 2005, 15, 405-412.

20 E. Cukierman, R. Pankov and K. M. Yamada, Curr. Opin. Cell Biol., 2002, 14, 633-639.

21 E. G. Velliou, S. B. D. Santos, M. M. Papathanasiou, M. Fuentes-Gari, R. Misener, N. Panoskaltsis, E. N. Pistikopoulos and A. Mantalaris, Bioprocess Biosyst. Eng., 2015, 38, 1589-1600.

22 M. Mattie, A. Christensen, M. S. Chang, W. Yeh, S. Said, Y. Shostak, L. Capo, A. Verlinsky, Z. An, I. Joseph, Y. Zhang, S. Kumar-Ganesan, K. Morrison, D. Stover and P. Challita-Eid, Neoplasia, 2013, 15, 1138-1150.

23 P. A. Perez-Mancera, C. Guerra, M. Barbacid and D. A. Tuveson, Gastroenterology, 2012, 142, 1079-1092.

24 K. P. Olive, M. A. Jacobetz, C. J. Davidson, A. Gopinathan, D. McIntyre, D. Honess, B. Madhu, M. A. Goldgraben, M. E. Caldwell and D. Allard, Science, 2009, 324, 1457-1461. 25 A. Richmond and Y. Su, Dis. Models \& Mech., 2008, 1, 78-82. 26 S. Loisel, M. Ohresser, M. Pallardy, D. Daydé, C. Berthou, G. Cartron and H. Watier, Crit. Rev. Oncol. Hematol., 2007, 62, 34-42.

27 S. Y. Cho, W. Kang, J. Y. Han, S. Min, J. Kang, A. Lee, J. Y. Kwon, C. Lee and H. Park, Mol. Cells, 2016, 39, 77-86.

28 E. K. Colvin and C. J. Scarlett, Semin. Cell Dev. Biol., 2014, 27, 96-105.

29 M. Hogenes, M. Huibers, C. Kroone and R. de Weger, Transplant. Rev., 2014, 28, 103-110.

30 F. J. O'Brien, Mater. Today, 2011, 14, 88-95.

31 B. Dhandayuthapani, Y. Yoshida, ToruMaekawa and D. S. Kumar, Int. J. Polym. Sci., 2011, 2011, DOI: 10.1155/ 2011/290602.

32 E. Burdett, K. Kasper, A. G. Mikos and J. A. Ludwig, Tissue Eng., Part B, 2010, 16, 351-359.
33 T. G. Fernandes, M. M. Diogo, D. S. Clark, J. S. Dordick and J. M. S. Cabral, Trends Biotechnol., 2009, 27, 342-349.

34 D. Gaspar and D. I. Zeugolis, Drug Discovery Today, 2016, 21, 1341-1344.

35 L. Meli, H. S. C. Barbosa, A. M. Hickey, L. Gasimli, G. Nierode, M. M. Diogo, R. J. Linhardt, J. M. S. Cabral and J. S. Dordick, Stem Cell Res., 2014, 13, 36-47.

36 D.-D. Wang, W. Liu, J.-J. Chang, X. Cheng, X.-Z. Zhang, H. Xu, D. Feng, L.-J. Yu and X.-L. Wang, RSC Adv., 2016, 6, 24083-24090.

37 P. Longati, X. Jia, J. Eimer, A. Wagman, M.-R. Witt, S. Rehnmark, C. Verbeke, R. Toftgård, M. Löhr and R. L. Heuchel, BMC Cancer, 2013, 13, DOI: 10.1186/14712407-13-95.

38 Y. Matsuda, T. Ishiwata, Y. Kawamoto, K. Kawahara, W.-X. Peng, T. Yamamoto and Z. Naito, Med. Mol. Morphol., 2010, 43, 211-217.

39 S. F. Boj, C. I. Hwang, L. A. Baker, D. D. Engle, D. A. Tuveson and H. Clevers, Mol. Cell. Oncol., 2016, 3, e1014757.

40 S. F. Boj, C. I. Hwang, L. A. Baker, I. I. C. Chio, D. D. Engle, V. Corbo, M. Jager, M. Ponz-Sarvise, H. Tiriac, M. S. Spector, A. Gracanin, T. Oni, K. H. Yu, R. van Boxtel, M. Huch, K. D. Rivera, J. P. Wilson, M. E. Feigin, D. Ohlund, A. Handly-Santana, C. M. Ardito-Abraham, M. Ludwig, E. Elyada, B. Alagesan, G. Biffi, G. N. Yordanov, B. Delcuze, B. Creighton, K. Wright, Y. Park, F. H. Morsink, I. Q. Molenaar, I. H. Borel Rinkes, E. Cuppen, Y. Hao, Y. Jin, I. J. Nijman, C. Iacobuzio-Donahue, S. D. Leach, D. J. Pappin, M. Hammell, D. S. Klimstra, O. Basturk, R. H. Hruban, G. J. Offerhaus, R. G. Vries, H. Clevers and D. A. Tuveson, Cell, 2015, 160, 324-338.

41 M. J. Ware, V. Keshishian, J. J. Law, J. C. Ho, C. A. Favela, P. Rees, B. Smith, S. Mohammad, R. F. Hwang, K. Rajapakshe, C. Coarfa, S. Huang, D. P. Edwards, S. J. Corr, B. Godin and S. A. Curley, Biomaterials, 2016, 108, 129-142.

42 V. Brancato, V. Comunanza, G. Imparato, D. Corà, F. Urciuolo, A. Noghero, F. Bussolino and P. A. Netti, Acta Biomater., 2017, 49, 152-166.

43 M. J. Ware, K. Colbert, V. Keshishian, J. Ho, S. J. Corr, S. A. Curley and B. Godin, Tissue Eng., Part C, 2016, 22, 312-321.

44 Z. Wen, Q. Liao, Y. Hu, L. You, L. Zhou and Y. Zhao, Braz. J. Med. Biol. Res., 2013, 46, 634-642.

45 C. I. Hwang, S. F. Boj, H. Clevers and D. A. Tuveson, J. Pathol., 2016, 238, 197-204.

46 F. Chiellini, D. Puppi, A. M. Piras, A. Morelli, C. Bartoli and C. Migone, $R S C$ Adv., 2016, 6, 54226-54235.

47 C. S. Ki, T.-Y. Lin, M. Korc and C.-C. Lin, Biomaterials, 2014, 35, 9668-9677.

48 A. Raza, C. S. Ki and C.-C. Lin, Biomaterials, 2013, 24, 51175127.

49 C. Ricci, C. Mota, S. Moscato, D. D'Alessandro, S. Ugel, S. Sartoris, V. Bronte, U. Boggi, D. Campani, N. Funel, L. Moroni and S. Danti, Biomatter, 2014, 4, e955386.

50 X. Wang, X. Zhang, Z. Fu and H. Yina, J. Biotechnol., 2013, 166, 166-179. 
51 Q. He, X. Wang, X. Zhang, H. Han, B. Han, J. Xu, K. Tang, Z. Fu and H. Yin, Int. J. Nanomed., 2013, 8, 1167-1176.

52 M. C. Allenby, R. Misener, N. Panoskaltsis and A. Mantalaris, Tissue Eng., Part C, 2017, 23, 108-117.

53 E. Velliou, M. Fuentes-Garí, R. Misener, E. Pefani, M. Rende, N. Panoskaltsis, A. Mantalaris and E. N. Pistikopoulos, Comput.-Aided Chem. Eng., 2014, 34, 225-236.

54 M. Fuentes-Garía, E. Velliou, R. Misener, E. Pefani, M. Rende, N. Panoskaltsis, A. Mantalaris and E. N. Pistikopoulos, Comput. Chem. Eng., 2015, 81, 80-93.

55 T. M. Blanco, A. Mantalaris, A. Bismarck and N. Panoskaltsis, Biomaterials, 2010, 31, 2243-2251.

56 C. Ricci, L. Moroni and S. Danti, OA Tissue Engineering, 2013, 1, 4-10.

57 P. Lu, V. M. Weaver and Z. Werb, J. Cell Biol., 2012, 196, 395406.

58 D. I. Zeugolis, G. R. Paul and G. Attenburrow, J. Biomed. Mater. Res., Part A, 2009, 89, 895-908.

59 R. Nigam and B. Mahanta, J. Tissue Sci. Eng., 2014, 5, 137141.

60 G. BaoLin and P. X. Ma, Sci. China: Chem., 2014, 57, 490-500. 61 H. Janik and M. Marzec, Mater. Sci. Eng., C, 2015, 48, 586591.

62 J. Kucinska-Lipka, I. Gubanska and H. Janik, Sci. World J., 2013, 2013, 450132.

63 J. Guan, K. L. Fujimoto, M. S. Sacks and W. R. Wagner, Biomaterials, 2005, 26, 3961-3971.

64 S. Grad, L. Kupcsik, K. Gorna, S. Gogolewski and M. Alini, Biomaterials, 2003, 24, 5163-5171.

65 I. C. Bonzani, R. Adhikari, S. Houshyar, R. Mayadunne, P. Gunatillake and M. M. Stevens, Biomaterials, 2007, 28, 423-433.

66 L. Safinia, J. J. Blaker, V. Maquet, A. R. Boccaccini, A. Mantalaris and A. Bismarck, e-Polym., 2005, 5, DOI: 10.1515/epoly.2005.5.1.92.

67 L. Safinia, A. Mantalaris and A. Bismarck, Langmuir, 2006, 22, 3235-3242.

68 M. Panos, T. Z. Sen and M. G. Ahunbay, Langmuir, 2012, 28, 12619-12628.

69 Y. Zhang, C. Chai, X. S. Jiang, S. H. Teoh and K. W. Leong, Mater. Sci. Eng., C, 2007, 27, 213-219.

70 D. M. Salvay, C. B. Rives, X. Zhang, F. Chen, D. B. Kaufman, W. L. Lowe, Jr. and L. D. Shea, Transplantation, 2008, 85, 1456-1464.

71 D. Rajendran, A. Hussain, D. Yip, A. Parekh, A. Shrirao and C. H. Cho, J. Biomed. Mater. Res., Part A, 2017, 105, 21192128.

72 E. L. Deer, J. Gonzalez-Hernandez, J. D. Coursen, J. E. Shea, J. Ngatia, C. L. Scaife, M. A. Firpo and S. J. Mulvihill, Pancreas, 2010, 39, 425-435.

73 B. Sipos, S. Möser, H. Kalthoff, V. Török, M. Löhr and G. Klöppel, Virchows Arch., 2003, 442, 444-452.

74 C. He and D. J. Klionsky, Annu. Rev. Genet., 2009, 43, 67-93. 75 M. Topalovski and R. A. Brekken, Cancer Lett., 2016, 381, 252-258.
76 T. Imamura, H. Iguchi, T. Manabe, G. Ohshio, T. Yoshimura, Z. H. Wang, H. Suwa, S. Ishigami and M. Imamura, Pancreas, 1995, 11, 357-364.

77 K. C. Wood, Cancer Res., 2015, 75, 4247-4251.

78 J. P. O'Connor, E. O. Aboagye, J. E. Adams, H. J. Aerts, S. F. Barrington, A. J. Beer, R. Boellaard, S. E. Bohndiek, M. Brady, G. Brown, D. L. Buckley, T. L. Chenevert, L. P. Clarke, S. Collette, G. J. Cook, N. M. deSouza, J. C. Dickson, C. Dive, J. L. Evelhoch, C. Faivre-Finn, F. A. Gallagher, F. J. Gilbert, R. J. Gillies, V. Goh, J. R. Griffiths, A. M. Groves, S. Halligan, A. L. Harris, D. J. Hawkes, O. S. Hoekstra, E. P. Huang, B. F. Hutton, E. F. Jackson, G. C. Jayson, A. Jones, D. M. Koh, D. Lacombe, P. Lambin, N. Lassau, M. O. Leach, T. Y. Lee, E. L. Leen, J. S. Lewis, Y. Liu, M. F. Lythgoe, P. Manoharan, R. J. Maxwell, K. A. Miles, B. Morgan, S. Morris, T. Ng, A. R. Padhani, G. J. Parker, M. Partridge, A. P. Pathak, A. C. Peet, S. Punwani, A. R. Reynolds, S. P. Robinson, L. K. Shankar, R. A. Sharma, D. Soloviev, S. Stroobants, D. C. Sullivan, S. A. Taylor, P. S. Tofts, G. M. Tozer, M. van Herk, S. Walker-Samuel, J. Wason, K. J. Williams, P. Workman, T. E. Yankeelov, K. M. Brindle, L. M. McShane, A. Jackson and J. C. Waterton, Nat. Rev. Clin. Oncol., 2017, 14, 169-186.

79 W. H. Chen, J. S. Horoszewicz, S. S. Leong, T. Shimano, R. Penetrante, W. H. Sanders, R. Berjian, H. O. Douglass, E. W. Martin and T. M. Chu, In Vitro, 1982, 18, 24-34.

80 B. Matta-Domjan, A. King, S. Totti, C. Matta, G. Dover, P. Martinez, A. Zakhidov, R. La Ragione, H. Macedo, I. Jurewicz, A. Dalton and E. G. Velliou, J. Biomed. Mater. Res., Part B, 2017, DOI: 10.1002/jbm.b.34012.

81 M. E. Madden and M. P. Sarras Jr., Pancreas, 1988, 3, 512528.

82 K. Zeeberg, R. A. Cardone, M. R. Greco, M. Saccomano, A. Nohr-Nielsen, F. Alves, S. F. Pedersen and S. J. Reshkin, Int. J. Oncol., 2016, 49, 243-252.

83 M. Ignat, M. Aprahamian, V. Lindner, A. Altmeyer, S. Perretta, B. Dallemagne, D. Mutter and J. Marescaux, Gastroenterology, 2009, 137, 1584-1592.

84 Z. Cruz-Monserrate, C. L. Roland, D. Deng, T. Arumugam, A. Moshnikova, O. A. Andreev, Y. K. Reshetnyak and C. D. Logsdon, Sci. Rep., 2014, 4, 4410.

85 S. E. Kim, H.-J. Park, H. K. Jeong, M.-J. Kim, M. Kim, O.-N. Bae and S.-H. Baek, Biochem. Biophys. Res. Commun., 2015, 463, 205-210.

86 A. V. Salnikov, L. Liu, M. Platen, J. Gladkich, O. Salnikova, E. Ryschich, J. Mattern, G. Moldenhauer, J. Werner, P. Schemmer, M. W. Büchler and I. Herr, PLoS One, 2012, 7, e46391.

87 S. Nath and G. R. Devi, Pharmacol. Ther., 2016, 163, 94-108. 88 E. Knight and S. Przyborski, J. Anat., 2015, 227, 746-756.

89 I. Dufau, C. Frongia, F. Sicard, L. Dedieu, P. Cordelier, F. Ausseil, B. Ducommun and A. Valette, BMC Cancer, 2012, 12, 15.

90 H. Miyamoto, T. Murakami, K. Tsuchida, H. Sugino, H. Miyake and S. Tashiro, Pancreas, 2004, 28, 38-44. 
91 A. G. Lowrie, D. M. Salter and J. A. Ross, Br. J. Cancer, 2004, 91, 1327-1334.

92 B. Da Rocha-Azevedo, C.-H. Ho and F. Grinnell, Exp. Cell Res., 2013, 319, 546-555.

93 S. Linder, E. Castaños-Velez, A. von Rosen and P. Biberfeld, Hepato-Gastroenterology, 2001, 48, 1321-1327.

94 M. T. Yip-Schneider, H. Wu, K. Stantz, N. Agaram, P. A. Crooks and C. M. Schmidt, BMC Cancer, 2013, 13, 194.
95 M. Matsusaki, M. Komeda, S. Mura, H. Y. Tanaka, M. R. Kano, P. Couvreur and M. Akashi, Adv. Healthcare Mater., 2017, 6, 1700057.

96 V. B. Orel, M. A. Zabolotny and V. E. Orel, Med. Hypotheses, 2017, 102, 82-86.

97 N. C. Denko, Nat. Rev. Cancer, 2008, 8, 705-713.

98 A. C. Koong, V. K. Mehta, Q. T. Le, G. A. Fisher, D. J. Terris, J. M. Brown, A. J. Bastidas and M. Vierra, Int. J. Radiat. Oncol., Biol., Phys., 2000, 48, 919-922. 